\title{
A Comparison of efficacy of I/N Iron V/S Oral Iron for management of iron deficiency anemia in pregnant women in a tertiary care center
}

\author{
Kalra S. ${ }^{1}$, Goel J. ${ }^{2 *}$, Sah S. ${ }^{3}$, Arya S. ${ }^{4}$ \\ DOI: https://doi.org/10.17511/joog.2020.i04.02 \\ 1 Sakshi Kalra, JR-3, Department of Obstetrics and Gynecology, Shri Ram Murti Smarak Institute Of Medical Sciences, Bareilly, Uttar \\ Pradesh, India. \\ 2* J.K Goel, HOD and Professor, Department of Obstetrics and Gynecology, Shri Ram Murti Smarak Institute Of Medical Sciences, Bareilly, \\ Uttar Pradesh, India. \\ ${ }^{3}$ Shanti Sah, Associate Professor, Department of Obstetrics and Gynecology, Shri Ram Murti Smarak Institute Of Medical Sciences, Bareilly, \\ Uttar Pradesh, India. \\ 4 Shashibala Arya, Professor, Department of Obstetrics and Gynecology, Shri Ram Murti Smarak Institute Of Medical Sciences, Bareilly, \\ Uttar Pradesh, India.
}

Introduction: WHO defines anemia in pregnant women as hemoglobin level $<11 \mathrm{gm} / \mathrm{dL}$ and a hematocrit of $<0.33$. The number of patients with iron deficiency anemia is $>2$ billion which accounts for $30 \%$ of the world's population. The incidence of iron deficiency anemia in India is around $50 \%$. Material and Methods: A study was performed in the Department of Obstetrics and Gynecology, Shri Ram Murti Smarak Institute of Medical Sciences, Bareilly, Uttar Pradesh, India on 100 antenatal patients with nutritional anemia gestational age of 14-36 weeks. Group A was treated with intravenous iron sucrose and group B was treated with oral iron sulfate. Pretreatment hemoglobin, S. ferritin levels, and General Blood Picture were recorded. Results: The mean improvement of hemoglobin among $\mathrm{I} / \mathrm{V}$ and Oral iron following treatment was $1.68 \pm 0.33 \mathrm{gm} / \mathrm{dl}$ and $0.96 \pm 0.31$ $\mathrm{gm} / \mathrm{dl}$ respectively which was statistically significant. The improvement in iron stores was also observed more in the I/V group with a rise of S. ferritin of $27.21 \pm 9.5 \mathrm{ng} / \mathrm{ml}$ against a rise of $3.72 \pm$ $0.7 \mathrm{ng} / \mathrm{ml}$ in the oral group. Conclusion: Intravenous iron sucrose is safe and more effective than oral iron therapy in the treatment of iron deficiency anemia and to restore iron stores in pregnant women.

Keywords: Anaemia, Iron deficiency, Iron sucrose, S. ferritin

Corresponding Author

J.K Goel, HOD and Professor, Department of Obstetrics and Gynecology, Shri Ram Murti Smarak Institute Of Medical Sciences, Bareilly, Uttar Pradesh, India.

Email: drik309@gmail.com

\section{How to Cite this Article}

Kalra S, Goel JK, Sah S, Arya S. A Comparison of efficacy of I/V Iron V/S Oral Iron for management of iron deficiency anemia in pregnant women in a tertiary care center. Obs Gyne Review J Obstet Gynecol. 2020;6(4):79-84.

Available From

https://obstetrics.medresearch.in/index.php/joog/art icle/view/110
To Browse

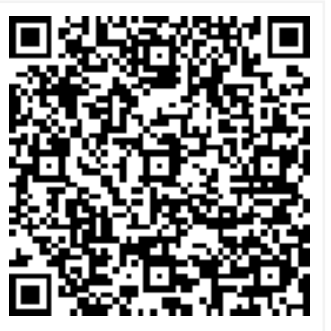

Manuscript Received 2020-05-26

Conflict of Interest No 2020-06-20

Funding Nil

Review Round 2
2020-07-01
$\begin{gathered}\text { Ethical Approval } \\ \text { Yes }\end{gathered}$

Review Round 2

Yes
Review Round 3 $6 \%$
Plagiarism X-checker

Accepted 2020-08-26

(c) 2020 by Sakshi Kalra, J.K Goel, Shanti Sah, Shashibala Arya and Published by Siddharth Health Research and Social Welfare Society. This is an Open Access article licensed under a Creative Commons Attribution 4.0 International License https://creativecommons.org/licenses/by/4.0/ unported [CC BY 4.0]. 


\section{Introduction}

Anemia affects nearly half of all pregnant women in the world. The global prevalence of anemia during pregnancy as estimated by WHO is $47.4 \%$ which is $14 \%$ in developed countries and $51 \%$ in developing countries [1]. The incidence of anemia during pregnancy in India ranges from 65\%-75\%. According to a FOGSI-WHO study, anemia is responsible for $64.4 \%$ of maternal deaths in India [2]. It is established that anemia directly accounts for $20 \%$ and indirectly $20-40 \%$ maternal deaths in India $[3,4]$. Anemia is also associated with increased risk of IUGR, preeclampsia (31\%), preterm labor (28\%), puerperal sepsis, lactational failure and delayed wound healing [5]. Poor socioeconomic conditions, incomplete knowledge, and increased dietary requirements of pregnant women are responsible for iron deficiency in our country. This is further aggravated by blood loss during pregnancy and delivery. Hence prevention and correction of anemia during pregnancy are necessary for safe motherhood. Indian data indicate that maternal morbidity rates are higher in women with hemoglobin below $8 \mathrm{~g} \%$. Maternal mortality shows a steep increase when maternal hemoglobin falls below $5 \mathrm{~g} \%$. So it is that segment of moderate iron deficiency anemia which is required to be treated vigorously in the second trimester itself. WHO technical group working on prevention and treatment of anemia documented that parenteral iron therapy produces a rapid and complete response to iron deficiency anemia than oral iron therapy.

\section{Objectives}

- To study the effectiveness of I/V iron in the management of iron deficiency anemia in pregnancy

- To study the effectiveness of oral iron in the management of iron deficiency anemia in pregnancy

- To compare the effectiveness of I/V iron v/s oral iron in the management of iron deficiency anemia in pregnancy

- To compare the safety of I/V iron V/S oral iron

\section{Material and Methods}

This is a hospital-based prospective case study conducted in the Department of Obstetrics and Gynecology in Shri Ram Murti Smarak Institute of
Medical Sciences, Bareilly, Uttar Pradesh, India wherein a total of 100 antenatal patients, who fulfilled the inclusion and exclusion criteria, were recruited over a period of October 2017 to April 2019. The patients enrolled in the study were assessed using the self-prepared semi-structured clinical datasheet.

\section{Inclusion criteria}

01. Singleton pregnancy

02. Gestational age between 14-36 weeks

03. Hemoglobin levels between 7-10 gm\%

\section{Exclusion criteria}

01. Multiple pregnancies

02. Gestational age $<14$ weeks and $>36$ weeks

03. Haemoglobin $<7 \mathrm{gm} \%$

04. H/O bleeding disorders, hemoglobinopathies, chronic illness, fever

They were divided into two groups- $A$ and $B$ comprising each of 50 patients matched according to age, parity, residence, and socioeconomic status.

In group $\mathrm{A}$ (study group), patients were given intravenous iron (Iron sucrose), no test dose was given. The total dose of iron sucrose was calculated from the following formula:

Weight $(\mathrm{Kg}) \times($ Target $\mathrm{Hb}-$ Initial $\mathrm{Hb}) \times 2.4+500$ mg (Ganzoni formula)

- Target haemoglobin was taken as $14 \mathrm{gm} / \mathrm{dl}$

- In group B(control group), patients were given oral iron (Ferrous Sulphate), wherein two tablets of iron each containing $60 \mathrm{mg}$ elemental iron were given with $5 \mathrm{mg}$ folic acid daily for 4 weeks.

- Hemoglobin estimation was done with $2 \mathrm{ml}$ of venous blood taken in an EDTA vial and was processed in a fully automated cell ( 5 part cell counter) machine by the Cyanmethhaemoglobin method.

- S.ferritin estimation was done with $2 \mathrm{ml}$ of venous blood taken in the plain vial and was processed in a fully automated VIDAS machine by the chemiluminescence method.

- Subsequently, the data thus collected were tabulated and statistically analyzed using IBM SPSS version 22. A P-value of less than 0.05 was considered statistically significant. 
- Initial hemoglobin and S. ferritin were recorded at the time of enrollment. During the course of treatment, any adverse reactions if occurred were recorded in both the groups. Patients were followed up at the second visit after 4 weeks when repeat hemoglobin and S.ferritin were recorded.

\section{Results}

\begin{tabular}{|c|c|c|c|c|c|}
\hline & \multirow[t]{2}{*}{ Variables } & \multicolumn{2}{|c|}{ IV group } & \multicolumn{2}{|c|}{ Oral group } \\
\hline & & No. & $\%$ & No. & $\%$ \\
\hline \multirow[t]{6}{*}{ Age (years) } & $\mid<20$ & 4 & 8 & 3 & 6 \\
\hline & $21-25$ & 26 & 52 & 21 & 42 \\
\hline & $26-30$ & 13 & 26 & 22 & 44 \\
\hline & $30-35$ & 5 & 10 & 3 & 6 \\
\hline & $>35$ & 2 & 4 & 1 & 2 \\
\hline & Mean & \multicolumn{2}{|c|}{$25.8 \pm 4.7$} & \multicolumn{2}{|c|}{$25.7 \pm 4.1$} \\
\hline \multirow[t]{3}{*}{ Socioeconomic status } & Lower & 31 & 62 & 34 & 68 \\
\hline & Middle & 18 & 36 & 16 & 32 \\
\hline & Upper & 1 & 2 & 0 & 0 \\
\hline \multirow[t]{3}{*}{ Gravidity } & G1 & 15 & 30 & 15 & 30 \\
\hline & G2 & 19 & 38 & 17 & 34 \\
\hline & $\geq \mathrm{G} 3$ & 16 & 32 & 18 & 36 \\
\hline \multirow[t]{6}{*}{ Gestational age (weeks) } & $14-20$ & 1 & 2 & 2 & 4 \\
\hline & $20.1-24$ & 1 & 2 & 0 & 0 \\
\hline & $24.1-28$ & 1 & 2 & 0 & 0 \\
\hline & $28.1-32$ & 4 & 8 & 12 & 24 \\
\hline & $32.1-36$ & 43 & 86 & 36 & 72 \\
\hline & Mean & \multicolumn{2}{|c|}{$32.9 \pm 3.5$} & \multicolumn{2}{|c|}{$32.6 \pm 3.4$} \\
\hline
\end{tabular}

100 antenatal anemic women between $20-40$ years were enrolled in the present study. The mean age in both the groups was $25.8 \pm 4.7$ years and $25.7 \pm 4.1$ years respectively.

The majority of them belonged to low socioeconomic status according to Modified Kuppuswamy Classification i.e. $31(62 \%)$ and $34(68 \%)$ in both the groups respectively. $30 \%$ cases in both groups were primigravidae,38\%, and $34 \%$ cases of gravida 2 while rest $32 \%$ and $36 \%$ cases were gravida 3 or more in I/V and oral iron groups respectively.

Maximum women belonged to $32.1-36$ weeks i.e. $86 \%$ and $72 \%$ in each group with the mean gestational age of $32.9 \pm 3.5$ weeks and $32.6 \pm 3.4$ weeks in group A and group B respectively.

Thus both the groups were comparable in demographic and obstetric profile as shown in Table 1 .
Table-2: Comparison of cases according to pre and post-treatment hemoglobin levels.

\begin{tabular}{|c|c|c|c|c|c|c|c|c|}
\hline \multirow{3}{*}{$\begin{array}{c}\text { Haemoglobin } \\
(\mathrm{g} / \mathrm{dl})\end{array}$} & \multicolumn{4}{|c|}{ IV iron (GROUP A) } & \multicolumn{4}{|c|}{ Oral iron (GROUP B) } \\
\hline & \multicolumn{2}{|c|}{ Pretreatment } & \multicolumn{2}{|c|}{ After 4} & \multicolumn{2}{|c|}{ Pretreatment } & \multicolumn{2}{|c|}{ After 4} \\
\hline & NO. & $\%$ & NO. & $\%$ & NO. & $\%$ & NO. & $\%$ \\
\hline 7-8 & 5 & 10 & 0 & 0 & 3 & 6 & 0 & 0 \\
\hline $8.1-9$ & 43 & 86 & 0 & 0 & 47 & 94 & 1 & 2 \\
\hline 9.1-9.9 & 2 & 4 & 24 & 48 & 0 & 0 & 47 & 94 \\
\hline$>10$ & 0 & 0 & 26 & 52 & 0 & 0 & 2 & 4 \\
\hline MEAN & \multicolumn{2}{|c|}{$8.39 \pm 0.31$} & \multicolumn{2}{|c|}{$10.07 \pm 0.27$} & \multicolumn{2}{|c|}{$8.5 \pm 0.29$} & \multicolumn{2}{|c|}{$9.46 \pm 0.30$} \\
\hline MEAN RISE & \multicolumn{4}{|c|}{$1.68 \pm 0.33$} & \multicolumn{4}{|c|}{$0.96 \pm 0.31$} \\
\hline$P$ value & \multicolumn{4}{|c|}{$<0.001$} & \multicolumn{4}{|c|}{$<0.001$} \\
\hline
\end{tabular}

The pretreatment hemoglobin level at recruitment was comparable in both the groups.

Mean hemoglobin rise was observed after 4 weeks of treatment from $8.39 \pm 0.31 \mathrm{~g} / \mathrm{dl}$ to $10.07 \pm 0.27$ $\mathrm{g} / \mathrm{dl}$ in $\mathrm{I} / \mathrm{V}$ iron group and $8.5 \pm 0.29 \mathrm{~g} / \mathrm{dl}$ to $9.46 \pm 0.30 \mathrm{~g} / \mathrm{dl}$ in the oral iron group which is statistically significant with a P-value of $<0.001$ as shown in Table 2.

Table-3: Comparison of cases according to pre and post-treatment $S$. ferritin level.

\begin{tabular}{|c|c|c|c|c|c|c|c|c|}
\hline \multirow{3}{*}{$\begin{array}{l}\text { S. Ferritin } \\
(\mathrm{ng} / \mathrm{ml})\end{array}$} & \multicolumn{4}{|c|}{ I/V IRON (GROUP A) } & \multicolumn{4}{|c|}{ ORAL IRON (GROUP B) } \\
\hline & \multicolumn{2}{|c|}{ Pretreatment } & \multicolumn{2}{|c|}{$\begin{array}{l}\text { After } 4 \\
\text { weeks }\end{array}$} & \multicolumn{2}{|c|}{ Pretreatment } & \multicolumn{2}{|c|}{$\begin{array}{l}\text { After } 4 \\
\text { weeks }\end{array}$} \\
\hline & NO. & $\%$ & NO. & $\%$ & NO. & $\%$ & NO. & $\%$ \\
\hline$<10$ & 12 & 24 & 0 & 0 & 12 & 24 & 2 & 4 \\
\hline $10.1-20$ & 34 & 68 & 1 & 2 & 33 & 66 & 34 & 68 \\
\hline 20.1-30 & 4 & 8 & 11 & 22 & 5 & 10 & 14 & 28 \\
\hline$>30$ & 0 & 0 & 38 & 76 & 0 & 0 & 0 & 0 \\
\hline MEAN & \multicolumn{2}{|c|}{$13.38 \pm 4.62$} & \multicolumn{2}{|c|}{$\begin{array}{l}40.59 \pm 13.6 \\
4\end{array}$} & \multicolumn{2}{|c|}{$13.69 \pm 5.10$} & \multicolumn{2}{|c|}{$17.40 \pm 4.83$} \\
\hline MEAN RISE & \multicolumn{4}{|c|}{$27.21 \pm 9.15$} & \multicolumn{4}{|c|}{$3.72 \pm 0.7$} \\
\hline$P$ value & \multicolumn{4}{|c|}{0.000} & \multicolumn{4}{|c|}{0.0003} \\
\hline
\end{tabular}

The pre-treatment S. ferritin levels were also similar in both the groups as shown in Table 3.

The mean S. ferritin among I/V iron group increased from an initial value of $13.38 \pm 4.6 \mathrm{ng} / \mathrm{ml}$ to $40.59 \pm 13.64 \mathrm{ng} / \mathrm{ml}$ compared to the increase from $13.69 \pm 5.10 \mathrm{ng} / \mathrm{ml}$ to $17.40 \pm 4.83 \mathrm{ng} / \mathrm{ml}$ in the Oral iron group which is statistically significant with a $\mathrm{P}$ value of 0.000 and 0.0003 in $\mathrm{I} / \mathrm{V}$ and oral iron groups respectively.

The rise in hemoglobin and $\mathrm{S}$. ferritin, which is a surrogate marker of iron deficiency, in both the groups was statistically significant, however, the increase was more in the I/V iron group. 
Table-4: Adverse reactions.

\begin{tabular}{|l|l|l|}
\hline \multicolumn{1}{|c|}{ Adverse reactions } & IV Group & Oral Group \\
\hline Nausea/Vomiting & 0 & 7 \\
\hline Constipation & 0 & 2 \\
\hline Sweating & 1 & 0 \\
\hline Breathlessness & 1 & 0 \\
\hline Itching & 1 & 0 \\
\hline Total & 3 & 9 \\
\hline
\end{tabular}

Minor gastrointestinal adverse effects were experienced by 9 women in the oral iron group in the form of nausea/vomiting among 7 women and constipation among 2 women. These nine patients were given other forms of oral iron preparation in the form of ferrous ascorbate. All the nine patients tolerated this form very well and none discontinued the study.

These gastrointestinal adverse effects were not seen with I/V iron, however, 3 women experienced breathlessness, sweating, and itching respectively after I/V iron administration which was mild and was managed conservatively as shown in Table 4.

\section{Discussion}

During normal pregnancy, due to a disproportionate increase in plasma volume and red cell mass, there is a physiological drop in hemoglobin of $\infty 2 \mathrm{~g} / \mathrm{dl}$ compared to non-pregnant women. But due to ignorance, lack of knowledge regarding nutrition amongst poor women, and increased dietary requirements during pregnancy makes them vulnerable to nutritional anemia mainly iron deficiency.

The same was observed in the present study wherein maximum cases belonged to low socioeconomic status according to Modified Kuppuswamy Classification.

The observations were similar to a study conducted by Umesh Kapil et al for the prevalence of multiple micronutrient deficiencies amongst pregnant women where data revealed that $31.8 \%$ of pregnant women were illiterate and the majority $(81.9 \%)$ belonged to lower-middle and middle socioeconomic status [6].

Anemia is more commonly observed in multigravida due to frequent childbirth, less spacing between subsequent pregnancies, and failure in the replenishment of their iron stores. It is generally believed that anemia in pregnancy increases with rising parity due to repeated drain on iron stores.

A similar observation was seen in the present study
Where maximum patients were multigravida which was inconsistent with the finding of Zama et al [7]. However, this was in contrast with the study by Ahmed $\mathrm{N}$ et al, who reported that primigravidae more often had anemia [8].

The majority of the anemic antenatal patients who were enrolled in the present study belonged to 3rd trimester with maximum cases detected at gestational age above 28 weeks with the mean gestational age of $32 \pm 3$ weeks i.e in early 3rd trimester.

This may be due to maximum change in plasma volume and RBC mass which occurs beyond 28 weeks leading to physiological hemodilution. Also, the increased demand of growing fetus and preferential transfer to fetus making women more anemic in the 3rd trimester.

Our finding was indifference with the study conducted by Pathak $P$ et al wherein anemia was more common in the early second trimester. Our finding was also discordant to the observation of Aggarwal Rohina $S$ et al [9] wherein the mean gestational age of anemic women were $28 \pm 1$ weeks and $21 \pm 1$ weeks in I/V and oral groups respectively.

A substantial increase in hemoglobin was observed in group $A$ rising from mean hemoglobin of $8.39 \pm 0.31 \mathrm{~g} / \mathrm{dl}$ to $10.07 \pm 0.27 \mathrm{~g} / \mathrm{dl}$ as well as in group B rising from $8.5 \pm 0.29 \mathrm{~g} / \mathrm{dl}$ to $9.46 \pm 0.30 \mathrm{~g} / \mathrm{dl}$ after 4 weeks treatment.

Thus, the mean rise in hemoglobin was $1.68 \pm 0.33$ $\mathrm{g} / \mathrm{dl}$ in group $A$ which was higher in comparison to $0.96 \pm 0.31 \mathrm{~g} / \mathrm{dl}$ in group $B$ with a significant $P$ value being $<0.001$ as only $10 \%$ of the ingested iron is absorbed while the rest of the iron forms insoluble oxides upon exposure to oxygen.

Also intravenous iron bypasses the first-pass metabolism and the iron sucrose complex releases rapidly to endogenous iron-binding proteins with no deposition in parenchymal tissues.

Similarly, there was a significant increase in iron stores with the rise of $\mathrm{s}$. ferritin from $13.38 \pm 4.62$ $\mathrm{ng} / \mathrm{ml}$ to $40.59 \pm 13.64 \mathrm{ng} / \mathrm{ml}$ with a mean rise of $27.21 \pm 9.15 \mathrm{ng} / \mathrm{ml}$ in group A compared to a rise of $\mathrm{ng} / \mathrm{ml} 17.40 \pm 4.83 \mathrm{ng} / \mathrm{ml}$ from an initial level of $13.69 \pm 5.10 \mathrm{ng} / \mathrm{ml}$, thus the mean rise was $3.72 \pm 0.7 \mathrm{ng} / \mathrm{ml}$ in group $B$.

The rise in both groups was statistically significant with a $p$-value of 0.000 and 0.0003 respectively. 


\section{Limitations}

However, this is a very small study. Large randomized trials are needed to compare the effectiveness of various routes of iron therapy in pregnant anaemic women.

Similar observations were seen in the following studies:

Table-5: Comparison of various studies with the present study in regard to the rise in hemoglobin.

\begin{tabular}{|l|l|l|l|l|l|}
\hline \multirow{2}{*}{ Authors } & Year & Rise of hemoglobin (g/dl) & P-value & Duration \\
\cline { 3 - 4 } & & I/V iron & Oral iron & & \\
\hline V Sunita et al [10] & 2015 & 2.28 & 0.73 & 0.001 & 4 weeks \\
\hline Rudra S et al [11] & 2016 & 2 & 1.27 & $<0.0001$ & 4 weeks \\
\hline Present study & 2019 & $1.68 \pm 0.33$ & $0.96 \pm 0.31$ & $<0.001$ & 4 weeks \\
\hline
\end{tabular}

Table-6: Comparison of various studies with the present study in regard to the rise in $S$. ferritin.

\begin{tabular}{|l|l|l|l|l|l|}
\hline \multicolumn{1}{|c|}{ Authors } & Year & Rise of S. ferritin (ng/ml) & P-value & Duration \\
\cline { 3 - 4 } & & I/V iron & Oral iron & & \\
\hline V Sunita et al [10] & 2015 & 19.04 & 8.5 & 0.001 & 4 weeks \\
\hline Rudra S et al [11] & 2016 & 25 & 3.61 & $<0.0001$ & 4 weeks \\
\hline Present study & 2019 & $27.21 \pm 9.15$ & $3.72 \pm 0.7$ & 0.000 & 4 weeks \\
\hline
\end{tabular}

No major adverse effects were seen in both groups. However, the compliance and tolerance of the iron formulation are to be considered for deciding the route of administration, and was seen that intravenous iron was better tolerated than oral iron.

\section{Conclusion}

In our country where women may become anemic due to ignorance, low socioeconomic status, repeated childbirth with less spacing, iron stores are to be corrected and intravenous iron sucrose is safe, convenient, and more effective than oral iron in the treatment of moderate anemia in 3rd trimester.

\section{What does the study add to the existing knowledge}

The current study further establishes the importance of oral iron in the treatment of moderate anemia in 3rd trimester.

\section{Author's contribution}

Dr. Sakshi Kalra: Concept, manuscript preparation

Dr. J.K Goel: Study design, data analysis
Dr. Shanti Sah: Data collection

Dr. Shashibala Arya: Manuscript preparation

\section{Reference}

01. De benoist B. (eds) Worldwide Prevalence of anemia 1993-2005. WHO Global Database on Anemia Geneva. 2008. Available at [Article] [Crossref]

02. Bhat R. Maternal mortality in India-FOGSI-WHO study. J Obstet Gynaecol India. 1997;47(3)207214.

[Crossref]

03. Kumar A, Jain S, Singh NP, Singh T. Oral versus high dose parentral iron supplementation in pregnancy. Int J Gynecol Obstet. 2005;89(1)713.

doi: 10.1016/j.ijgo.2005.01.016 [Crossref]

04. Malagi U, Reddy M, Naik R. Evaluation of national nutritional control programme in Dharward (Karnataka). J Hum Ecol. $2006 ; 20(4) 279-281$.

doi: $10.1080 / 09709274.2006 .11905939$ [Crossref]

05. Khurana A. Ultrasound in obstetric practice. Ian Donald's Practical Obstetrics Problems. 9/e. 2020 May $1 ; 61$ [Crossref]

06. Pathak P, Kapil U, Kapoor SK, Saxena R. Prevalence of multiple micronutrient deficiencies amongst pregnant women in a rural area of Haryana. Indian J Pediatr. 2004;71(11)10071014.

doi: $10.1007 / B F 02828117$ [Crossref]

07. Zama I, Argungu IB, Yakubu A, Taylor JR, Erhabor O, Suzette U. Socio-demographic and obstetric factors associated with anemia among pregnant women in Sokoto, North Western Nigeria. Am Assoc Sci Technol. 2014;1(5)119126.

[Crossref]

08. Rudra S, Chandna A, Nath J. Comparison of intravenous iron sucrose with oral iron in pregnant women with iron deficiency anemia. Int J Reprod Contracept Obstet Gynecol. 2016;5(3)747-751.

doi: $10.18203 / 2320-1770 . i j r c o g 20160577$ [Crossref] 
09. Tandon A, Gupta V, Chaudhary P, Kumari N. Comparison between intravenous iron sucrose versus oral iron iron therapy in pregnant women with nutritional anemia- a prospective study. Int J Reprod Contracept Obstet Gynecol. 2016;5(7)2278-2281.

doi: $10.18203 / 2320-1770 . i j r c o g 20162110$ [Crossref]
10. Aggarwal RS, Mishra VV, Panchal NA, Patel NH, Deshchougule VV, Jasani AF. Evaluation of iron sucrose and oral iron in the management of Iron Deficiency Aaemia in pregnancy. Nat J Comm Med. 2012;93(1)415-416.

[Crossref] 